\title{
THE ATTITUDE AND REAL CUSTOMER'S BEHAVIOR USING MOBILE BANKING IN BANK JATIM PARE
}

Rendi Suseno

Brawijaya University, Malang, Indonesia rendinetral@gmail.com

\begin{abstract}
The presence of modern banking service products such as mobile banking should meet the requirements of a technology to be adopted. In fact the problem that arises in the use of a technology at Bank Jatim is low utilization of the service system. This condition challenges researchers to test through technology acceptance model theory with modification of models to explain the conditions of acceptance of a new technology. The conclusion of this study found that from the model that had been compiled that the three exogenous variables were tested, only the ease of perception variables that proved to have a significant contribution to both attitudes of use and the actual behavior of use. In addition, perceived convenience variables also have a significant positive influence on customer trust. However, the results of the study found that the contribution of trust and trust variables was still low in shaping attitudes towards the use and real behavior of using mobile banking services. Another finding in this study to describe the problem of the low use of mobile banking services is the need for cash transactions by customers. Most PNS customers need cash transactions in their daily routine compared to the needs of non-cash transactions such as transfers or purchases online. This is what causes customers to use the Automated Teller Machine service as a means of taking their money and then use the transaction directly as needed.
\end{abstract}

Keywords: Perceived Ease of Use, Perceived Usefulness, Trust, Attitude Toward Using, Actual Usage

\section{INTRODUCTION}

The existence of new technology offers efficient solutions to the problems faced in everyday life. This condition also occurs in banks at this time, the banking industry goes through a fundamental phase of movement in the service model offered. Not just modernizing equipment owned, but more than that. Banking is faced with increasingly diverse customer needs with the demand for services that must be better, making it easier for customers. Current customer behavior is very different from customers five or ten years ago, now customers are increasingly critical of services, must encourage banks to have products that can answer customer needs. Of course banks must be able to 
optimize the investment that must be spent to offer these service products. The demands of customers who want fast, safe, convenient, inexpensive, available services at all times and can be accessed from mobile phones are answered by the birth of mobile banking. It is not only profitable for the customers because of efficiency, but on the banking side this service is also cheaper in terms of capital investment that must be spent compared to the procurement of automated teller machines or establishing subbranch offices.

The convenience of the customers by making transactions through mobile banking has been proven from the many service facilities contained in it, such as checking balances, sending money, or offering information services in it. These conveniences and the benefits obtained by customers increase the use of the mobile banking service system (Kaleem and Ahmad, 2008; Rigopoulos and Askounis, 2007; Islam and Chick, 2011; Lech, 2012, Choi, et all, 2011).

The prerequisite for the presence of mobile banking technology that should meet the needs of customers, is apparently a different case for the customers of Bank Jatim in the Pare branch. The existing technological advancements have not encouraged the increase in the use of mobile banking services. Data recorded until this research was conducted by the number of customers at Pare Bank Jatim Branch was around 33,000 people and 1057 mobile banking users did not reach $10 \%$ of total customers. What's interesting about the low number of uses of mobile banking has not been able to explain the correlation with the limitation of sub-branch offices which of course are only active on weekdays. Isn't that supposed to be the hindering conditions that encourage customers to switch to using mobile banking services in conducting their transactions.

This study chose the customers of civil servants, based on the number of civil servant customers who had a significant contribution, approximately $38 \%$ of customers at Bank Jatim Pare Branch. So with this amount it should have a considerable potential for penetration of the use of mobile banking. This is because Civil Servants are currently facilitated by the State Civil Service Agency with the provision of Electronic Employee Cards (KPE). Where on the card other than functioning as identification also functions as an ATM card that is integrated into Bank Jatim. In the ATM facility it can automatically be activated by the mobile banking facility. The ease of facilities provided by banks is intended to encourage all civil servants to use these mobile banking facilities.

The findings in the field indicate that the customers, still have some problems regarding doubts about the mobile banking product. Perception is formed because of the experience of customers regarding Bank Jatim's mobile banking service system which often experiences disturbance when using it, and there is a risk of losing money when making transactions that affect attitudes in using mobile banking services. So it is very important to provide evidence of trust to customers, because empirically some studies provide the conclusion that trust factors are very important in transactions involving technology (Suh and Han, 2002; Alsajjan and Dennis, 2009).

This research aims to explain the acceptance of mobile banking to customers by adopting and combining the theoretical concepts of consumer behavior and Technology Acceptance Model (TAM) in the context of mobile banking. The reason for choosing this TAM theory is that this theory offers a strong and simple explanation for the acceptance of technology and the behavior of its users (Davis, 1989). However, from a number of 
previous studies there are still very varied research results, of course by making various modifications to the original TAM model, encouraging researchers to do the same to retest the context of customers at Bank Jatim branch of Pare.

\section{LITERATURE REVIEW}

\section{Mobile Banking}

Mobile banking is one of the services presented by banks that allows customers to obtain information, communicate, and conduct banking transactions through cellular networks (Maharsi and Fenny, 2006).

\section{Trust}

The most important trust in online banking is because transactions carried out through online banking contain sensitive information and the parties involved are kept confidential about information transferred via the internet (Alsajjan and Dennis, 2009; Suh and Han, 2002).

\section{Technology Acceptance Model (TAM)}

The level of acceptance of mobile banking can be analyzed using the Technology Acceptance Model (TAM) model. Before the TAM model emerged, there was a theory known as Theory of Reasoned Action (TRA) developed by Martin Fishbein and Icek Ajzen $(1975,1980)$. TAM is one type of theory that uses a behavioral theory approach which is widely used to study the process of adopting information technology. Apparently, the TAM model and its indicators have been proven to measure technology acceptance. Thus using TAM will be able to explain why mobile banking technology can be accepted or not by users, namely banking customers. some subsequent studies modified the model according to needs as Davis did. Visually, the TAM model research conducted by Davis can be explained the perception of usefulness and ease of use will affect attitudes toward the use of information systems and then affect the intensity of use. After that it will affect the actual use of the system.

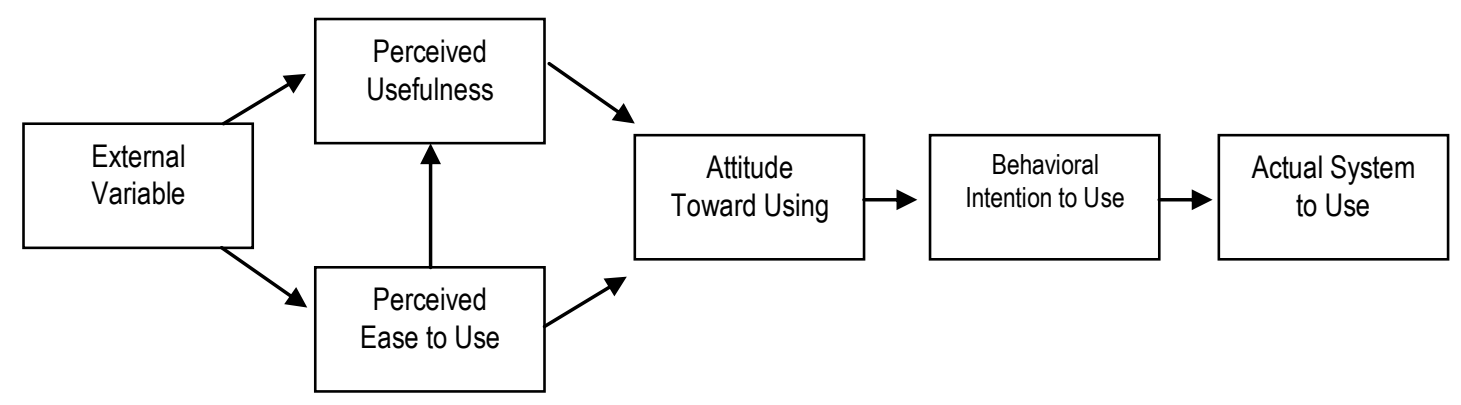

Figure 1. TAM Concept Model

\section{Perceived ease of use}

Perceived ease of use of a technology is defined as a measure where one believes that computers can be easily understood and used (Davis, 1993). 


\section{Perceived usefulness}

Perceived usefulness is defined as a measure where the use of a technology is believed to bring benefits to those who use it (Davis, 1989; Davis, 1993).

\section{Attitude toward using}

Attitude toward using in TAM is conceptualized as an attitude towards the use of systems in the form of acceptance or rejection as a result if someone uses a technology in his work (Davis, 1993).

\section{Actual system usage}

Actual system usage is the real behavior of banking customers in adopting a system (Davis, 1989).

\section{METHODS}

This study uses a quantitative approach design, by choosing causal research because it aims to obtain evidence of cause and effect between the research variables consisting of perceptions of ease of use, perceived usefulness, confidence in the attitude and real behavior of Bank Jatim PNS customers in using mobile services. banking. The study population is customers of civil servants who have access and have used mobile banking services which were recorded as many as 1057 customers. The research sample is in accordance with the structural equation model that uses an estimation of maximum likelihood estimation (MLE) model of 5-10 times the number of parameters estimated (Ghozali, 2004), so that the number of samples is 115 respondents. Data collection techniques using a questionnaire using a Likert scale with five alternative answers Strongly Disagree, Disagree, Neutral, Agree, Strongly Agree.

The data analysis technique used in this study is to use SEM (Structural Equation Model) with the AMOS (Analysis of Moment Structure) program. Modeling research through SEM allows a researcher to answer research questions that are regressive or dimensional in nature (ie measuring what dimensions of a concept are). The stages of modeling and analyzing structural equations are the following seven steps (Ferdinand, 2002):

(1) Model development based on theory; (2) Arrange the path diagram; (3) Convert flowcharts into a series of structural equations; (4) Selection of input matrices and estimation techniques for the model built; (5) Assess the possibility of identification problems; (6) Evaluation of the criteria for goodness of fit; (7) Model interpretation and modification.

The most important thing in this test is to see Goodness-of-fit used to measure the suitability of input observations with predictions from the proposed model Goodness-offit of the statistical model illustrates how suitable the model is with a set of observations. The goodness-of-fit index summarizes the differences between observed values and expected values under the statistical model. 
Table 1. Statistic fit model

\begin{tabular}{ll}
\hline Fit Statistics Model & Interpretation \\
\hline Model Chi-Square (CMIN) & Angka kecil dengan p >0.05 \\
Normed Chi-square (CMIN/DF) & $<3$ \\
RMR (Root Mean Square Residual) & Mendekati nol \\
GFI (Goodness of Fit Index) & $>0,90$ \\
AGFI (Adjusted GFI) & $>0,90$ \\
NFI (Normed Fit Index) & $>0,90$ \\
IFI (Incremental Fit Index) & $>0,90$ \\
CFI (Comparative Fit Index) & $>0,90$ \\
RMSEA (Root Mean Square Error & $<0,05$ (very good), o,05-0,08 (still \\
of Approximation) & accepted), >0,1 (not good) \\
\hline
\end{tabular}

The decision in testing the hypothesis in this study can be done by looking at the value of $C R>1.96$ and the value of $P<0.05$, there is a significant relationship between the variables tested. Vice versa. The research hypothesis is formulated as follows:

H1: Perception of ease of use has a direct positive effect on the attitude of using mobile banking.

H2: Perception of ease of use has a direct positive effect on trust in mobile banking usage.

H3: Perceived usefulness directly influences the attitude toward using mobile banking.

H4: Trust has a direct positive effect on the attitude toward using mobile banking.

H5: Trust has a direct and indirect positive effect on actual usage mobile banking.

H6: Perception of convenience has a direct and indirect positive effect on actual usage mobile banking.

H7: Perceived usefulness has a direct and indirect positive effect on actual usage mobile banking.

H8: The attitude toward using has a direct positive effect on actual usage mobile banking.

\section{RESULTS (AND OR DISCUSSION)}

\section{Overview of Respondents}

\section{Gender}

Respondents of this study were civil servants in the district of Pare, Kediri Regency with a total of 115 respondents. 
Table 2: Gender of Respondents

\begin{tabular}{lll}
\hline Gender & Frequency & Percentage (\%) \\
\hline Male & 52 & 45,2 \\
Female & 63 & 54,8 \\
\hline
\end{tabular}

The research data found that $54.8 \%$ of the study respondents were female civil servants (PNS), while male civil servants were $45.2 \%$. The use of Bank Jatim mobile banking in the working area of the Pare District apparently still dominated by female civil servants.

Age

The age range of civil servants (PNS) is quite diverse so that in this study the age composition was divided into four classifications of age ranging from under the age of 25 years to the age above the same as 46 years. With full explanation as follows:

Table 3: Age of Respondents

\begin{tabular}{lll}
\hline Age & Frequency & Persentage (\%) \\
\hline$\leq 25$ & 0 & 0 \\
$26-35$ & 47 & 40,9 \\
$36-45$ & 29 & 25,2 \\
$\geq 46$ & 39 & 33,9 \\
\hline
\end{tabular}

that the age range of 26-35 years dominates as many as $40.9 \%$ of mobile banking users at the Pare branch of Pare. It seems that the age factor has enough to contribute to the use of device-based services, followed by respondents with a age range above 46 years. , $9 \%$ in the second largest number of mobile banking users among civil servants (PNS) in Pare District.

\section{Group level}

Civil servants (PNS) are regulated on the ranks of career ranks which are divided into four groups, starting from the lowest career level in group one to the highest career level in group four, in each group divided into levels $A$ to $D$ while in group IV is divided into level A to E. Distribution of data at the level of rank group in this study is described as follows:

Table 4: Level of Rank Group

\begin{tabular}{ccc}
\hline Group level & Frequency & Persentage (\%) \\
\hline Gol I & 0 & 0 \\
Gol II & 2 & 1,7 \\
Gol III & 58 & 50,4 \\
Gol IV & 55 & 47,8 \\
\hline
\end{tabular}




\section{Monthly income}

The higher the level of the class of civil servants will be accompanied by an increase in income earned each month. The income referred to in this study is the salary and allowance obtained by civil servants every month.

Table 5. Monthly Income

\begin{tabular}{lll}
\hline Monthly income & Frequency & Percentage (\%) \\
\hline$<$ Rp2 million & 2 & 1,7 \\
Rp 2 million-Rp 5 & 67 & 58,3 \\
million & & \\
$>$ Rp 5 million & 46 & 40 \\
\hline
\end{tabular}

Mobile banking users are dominated by respondents with income of Rp2 million to Rp.5 million per month, 58.3\%, far greater than respondents with income above 5 million.

\section{Compilation Flowchart}

As explained earlier in the operational variables that in this study consisted of 5 constructs and 23 parameters which can be described in Figure 2 as follows:

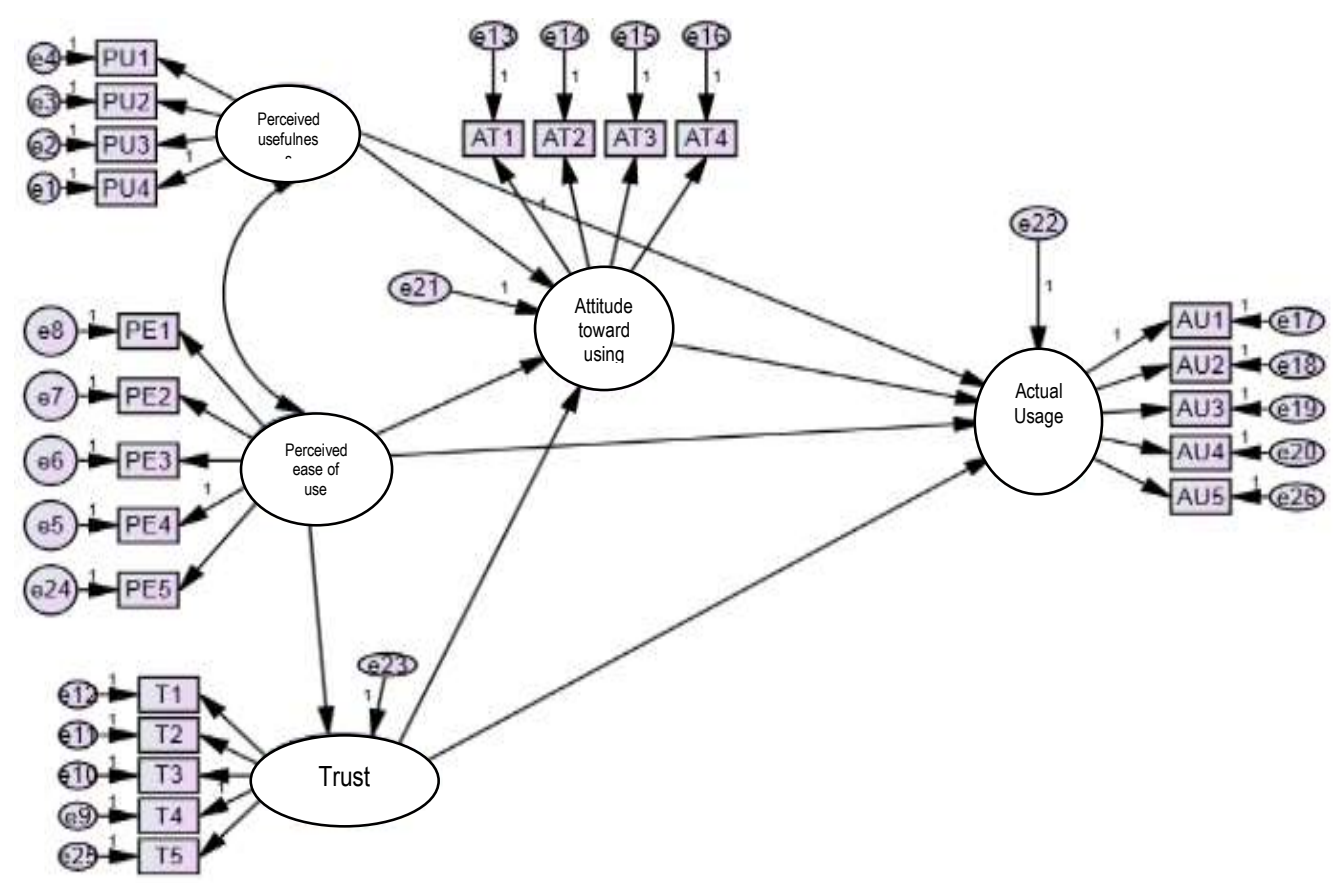

Figure 2. Model of Causality Relations Flow Chart

Based on the model in figure 2 it is denoted that the structural equation can be described as follows:

$A T=\beta 1 P U+\beta 2 P E+\beta 3 T+e 21$

$A U=\beta_{1} P U+\beta_{4} P U+\beta_{2} P E+\beta_{5} P E+\beta_{3} T+\beta 6 T+\beta_{7} T+e 22$ 
Explanation:

AT : Attitude toward using

AU : Actual Usage

PU : Perceived ease of use

PE : Perceived usefulness

T : Trust

Then a measurement model is carried out on the structural equation that has been compiled, as can be described in Figure 3 as the model below:

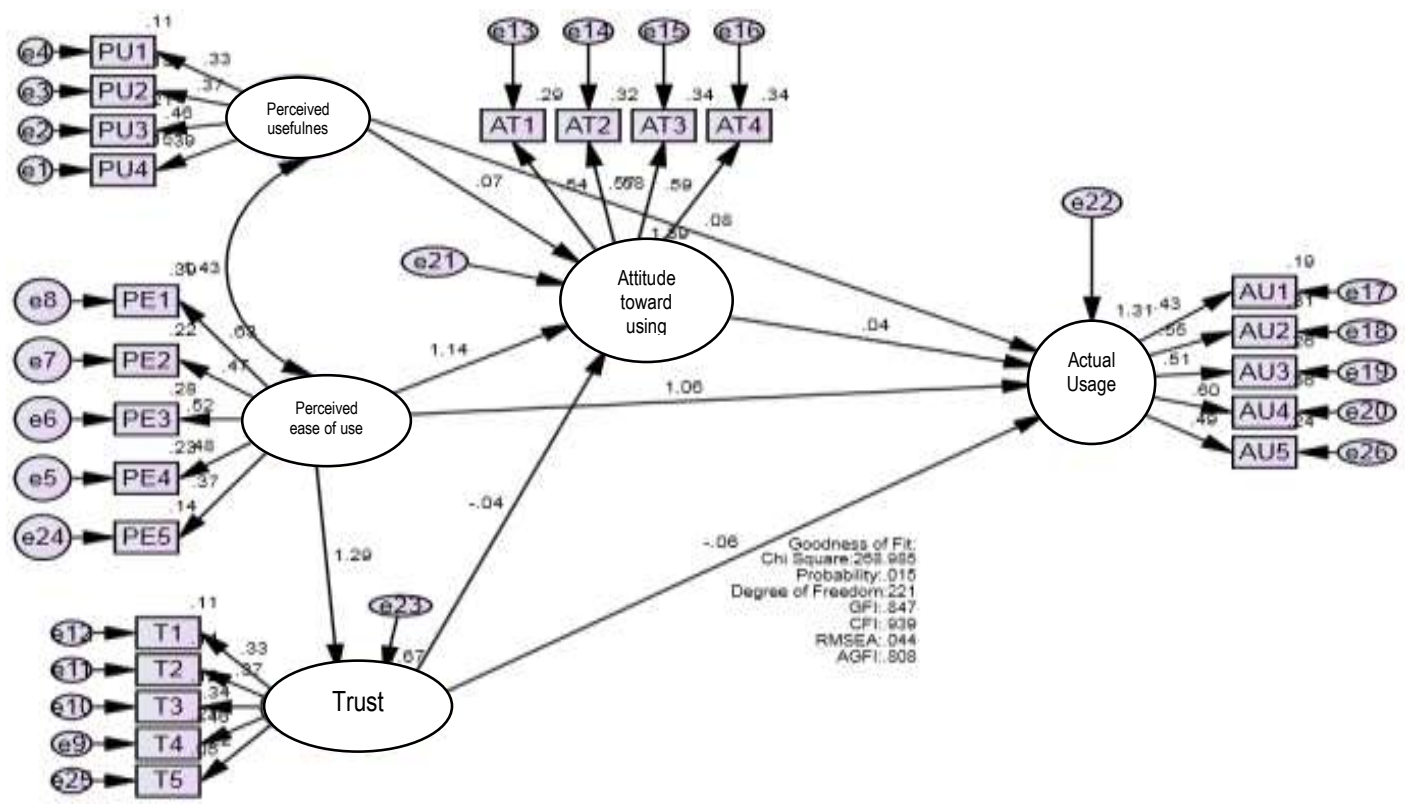

Figure 3. Full Structural Model

After the initial model is processed, the probability value of the model is 0.015, CMIN / DF of 1.217 is still close to the determination value of 2.00. The GFI value of 0.847 is still not close to 1 , the AGFI value of 0.808 is still not close to 1 , the RMSEA value of 0.044 is still more than 0.08 . The model is then modified by following the indies modification, modification is done with the aim of obtaining a value that matches the reference model equation value. The following are the details of the modification phase that was carried out:

\section{The First Stage}

Suggestions from Indies modification to combine measurement errors, only nine suggestions that can be done are19-19 e26 e17 e19 e15 e17 e14 e16 e12 e25 e10 e25 e6 e7 e5 e12 e5 e12 e2 e5 while other suggestions do not fulfill the requirements because theoretically it is not logical because of the independent variable on the dependent variable such as e15 which is an error AT3 is a mediating variable while e24 is an error PE5 is an independent variable, then e9-e17; e9-e20; e12-e17 . 


\section{Second stage}

In the second stage, a model improvement is based on the advice given, suggestions on regression weights on the model turned out to cause the formed model could not be properly identified so it was not feasible to do as in AU3-AU5, T1-T5; T3-T5; AU5-AU3; AU1-AU3; AU3-AU1; T5-T1 besides, some parameters that will be connected cannot be done because they occur with the observed variables of the independent variable, so suggestions cannot be made as in T2-AT4; AU1-T4. With these conditions, the suggestion is ignored to modify the model.

\section{Third phase}

After modifying the relationship path on the model, the results of the model tests that appear can be seen in Figure 4 as follows:

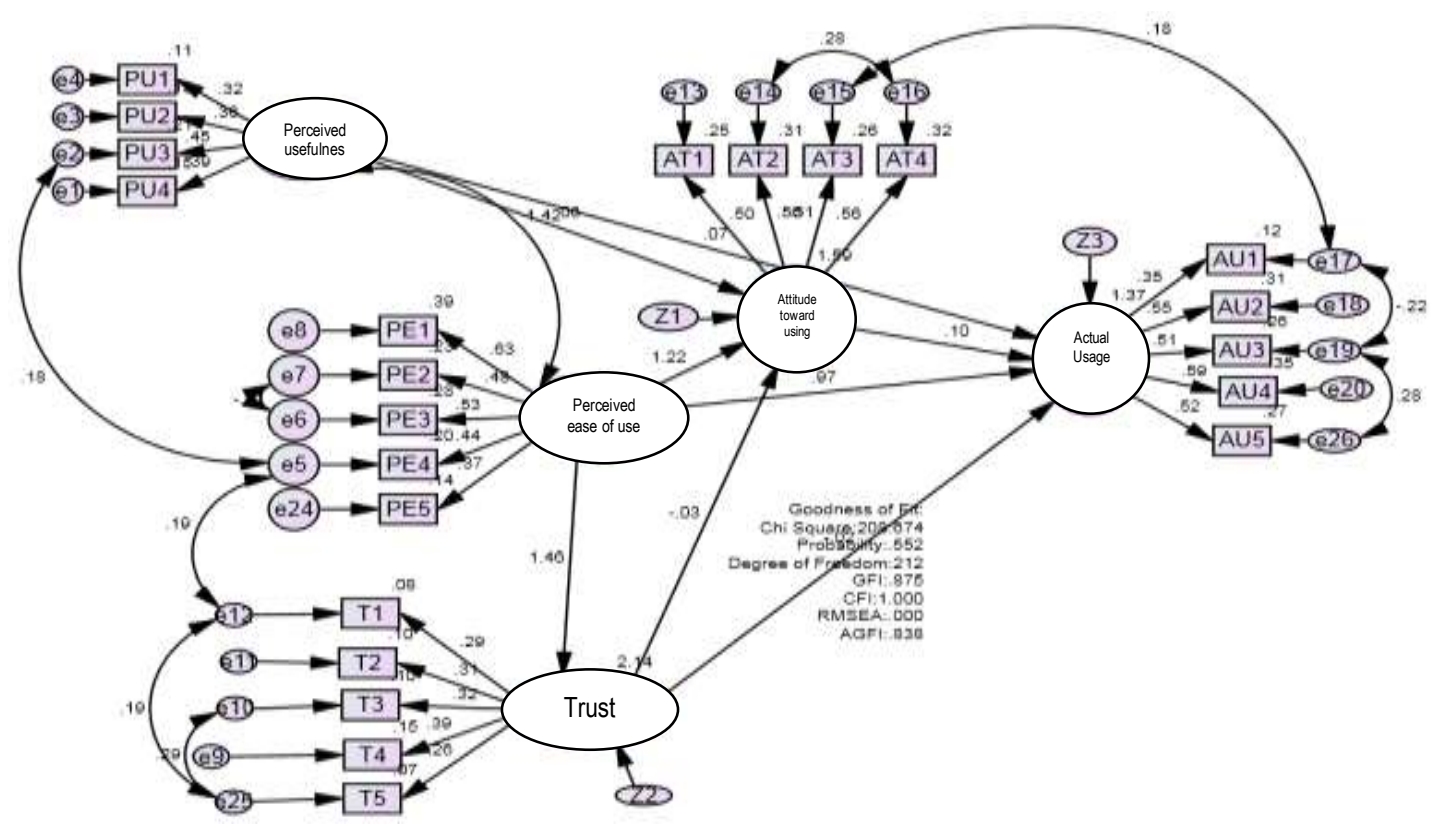

Figure 4. Modification Results Acceptance Model

The model of acceptance that has been prepared has been fit well, it can be seen from the value of chi square, CMIN / DF, GFI, AGFI, RMSEA, TLI and CFI which are in accordance with the structural reference value such as chi square 208,874 , probability of $0,552 \geq 005, \mathrm{GFI}$ is 0.875 close to $1, \mathrm{CFI}$ is $1,000 \geq 0.982$, RMSEA is $0,000 \leq 0.08$, while AGFI is 0.838 is close to 1 . The test results are better than the initial models so that this model can be accepted and used in research.

\section{Analysis of Direct Effect, Indirect Effect and Total Effect}

The results of the calculation of direct effect analysis in this research model are presented in table 6 as follows: 
Table 6. Standard Direct Effect

\begin{tabular}{lcrrrrr}
\hline & $\begin{array}{l}\text { Percei } \\
\text { ved } \\
\text { ease } \\
\text { of use }\end{array}$ & $\begin{array}{l}\text { Perceive } \\
\text { usefulne }\end{array}$ & ss & $\begin{array}{l}\text { Attitude } \\
\text { toward } \\
\text { Trust }\end{array}$ & $\begin{array}{r}\text { using } \\
\text { Actual } \\
\text { Usage }\end{array}$ \\
\hline $\begin{array}{l}\text { Trust } \\
\text { Attitude }\end{array}$ & 1.451 & 0 & 0 & 0 & 0 \\
toward using & 1.122 & 0.091 & 0.013 & 0 & 0 \\
& & & & 0.03 & & \\
Actual Usage & 0.842 & 0.07 & 5 & 0.146 & 0 \\
\hline
\end{tabular}

There is one direct influence on the variable trust, there are three variables that have a direct influence on the attitude of use, and there are four variables that have a direct influence on real behavior. From the calculation results, it can be explained that the variable that has the greatest direct influence on trust is the perception of convenience variable of 1,451. The variable that has the greatest direct influence on the attitude of use is the perceived convenience variable of 1,122 . While the ease of perception variable is also a variable that has the greatest influence on real behavior of 0.842 .

Table 7. Standard Indirect Effect

\begin{tabular}{|c|c|c|c|c|c|}
\hline & $\begin{array}{l}\text { Perceive } \\
\text { d ease of } \\
\text { use }\end{array}$ & $\begin{array}{l}\text { Perceived } \\
\text { usefulness }\end{array}$ & Trust & $\begin{array}{l}\text { Attitude } \\
\text { toward } \\
\text { using }\end{array}$ & $\begin{array}{l}\text { Actual } \\
\text { Usage }\end{array}$ \\
\hline Trust & 0 & 0 & 0 & 0 & 0 \\
\hline $\begin{array}{l}\text { Attitude toward } \\
\text { using }\end{array}$ & 0.018 & 0.013 & 0,002 & 0 & 0 \\
\hline Actual Usage & 0.217 & 0.043 & 0,019 & 0.075 & 0 \\
\hline
\end{tabular}

The results of the calculation of indirect effects between research variables can be presented in table 7, there are three variables that have an indirect influence on the attitude variable of use, and there are four variables that have an indirect influence on real behavior variables. The variable that has the greatest indirect influence on the attitude of use is the perceived convenience variable of 0.018 . While the variables that have the greatest indirect influence on real behavior are convenience perception variables of 0.217 .

The overall effect between variables in the model, then the calculation of the total effect presented in the standardized table of total effects is as follows: 
Table 8. Standardized Total Effects

\begin{tabular}{|c|c|c|c|c|c|}
\hline & $\begin{array}{l}\text { Perceived } \\
\text { ease of use }\end{array}$ & $\begin{array}{l}\text { Perceived } \\
\text { usefulness }\end{array}$ & Trust & $\begin{array}{l}\text { Attitude } \\
\text { toward } \\
\text { using }\end{array}$ & $\begin{array}{l}\text { Actual } \\
\text { Usage }\end{array}$ \\
\hline Trust & 1.451 & 0 & 0 & 0 & 0 \\
\hline $\begin{array}{l}\text { Attitude } \\
\text { toward using } \\
\text { Actual Usage }\end{array}$ & 1.141 & 0,091 & 0.013 & 0.146 & 0 \\
\hline Actual Usage & 1.059 & 0,083 & 0.036 & 0.075 & 0 \\
\hline
\end{tabular}

The variable that has the largest total influence on the use attitude variable is the convenience perception variable of 1,141 . While the variables that have the greatest total influence on real behavior are perceived convenience variables which are equal to 1,059.

\section{Perception of ease of use and attitude of using mobile banking}

The results of statistical tests that have been presented show that perceptions of convenience have a significant positive effect on the attitude of using car banking. Thus it can be concluded that the better the perception of ease in using mobile banking services will increase the attitude of using mobile banking. Some customers of civil servants who complain of difficulties in using mobile banking services triggered by technical or non-technical factors are ultimately unwilling to use mobile banking services and choose to use automated teller services for their transaction needs. The easier the technology is used it will trigger the transfer of customer behavior, if there is something that is easier and simpler why should do more difficult things. In fact the perception of convenience that has been formed in PNS customers is also able to influence their attitude towards mobile banking services provided by Bank Jatim. The ease of use of mobile banking will motivate customers to explore system features and functions in more detail.

\section{Perception of ease of use and attitude of using mobile banking}

The results of statistical tests that have been presented show that perceptions of convenience have a significant positive effect on the attitude of using car banking. Thus it can be concluded that the better the perception of ease in using mobile banking services will increase the attitude of using mobile banking. Some customers of civil servants who complain of difficulties in using mobile banking services triggered by technical or non-technical factors are ultimately unwilling to use mobile banking services and choose to use automated teller services for their transaction needs. The easier the technology is used it will trigger the transfer of customer behavior, if there is something that is easier and simpler why should do more difficult things. In fact the perception of convenience that has been formed on customers of civil servants is also able to influence their attitude towards mobile banking services provided by Bank Jatim. The ease of use of mobile banking will motivate customers to explore system features and functions in more detail. 


\section{Perception usefulness and attitudes of using mobile banking}

The results of the research that have been presented show that the perception of usefulness has a direct positive effect on the attitude of using mobile banking among civil servants but has a non-significant effect. These findings prove that the perception of expediency is not an important variable for customers of civil servants at the Bank Jatim Pare branch in influencing the attitude of using mobile banking. The findings of this study can illustrate how the attitude of the use of customers at Bank Jatim Pare is like the problem of the difficulty of civil servants to switch to using mobile banking services. Although they are aware of the benefits of using mobile banking services because they are often given socialization but have not formed an attitude towards the use of mobile banking services. This condition is also a proof that customers are not very concerned about these benefits if in practice they experience obstacles in the use of mobile banking services. The facts in the field also describe similar conditions in which the benefits that are known do not change the attitudes held by customers of Bank Jatim civil servants in bitter branches.

\section{Trust and attitude toward using mobile banking}

The findings in the study confirm that actual trust is not a variable that is considered important by customers at the Bank Jatim Pare branch. This can be seen from the insignificant influence between the trust variables on the attitude of use even though the hypothesis of this study proved correct if trust has a positive influence on the attitude of using mobile banking. Institutionally this bank has gained customer trust, only on this mobile banking service is a different issue for customers, considering that this service is still relatively new for customers over the age of 35 with limited understanding of new technologies. The low contribution of trust in mobile banking services is indeed related to the technical problem of the service itself which requires adequate internet service support and mobile phone qualifications used by customers.

\section{Trust and actual usage mobile banking}

The results of the research that have been presented show that trust is proven to have a direct or indirect positive influence on the real behavior of using mobile banking among civil servants but the effect is not significant. These findings prove that trust is not a variable that is an important consideration for customers in influencing the attitude of using mobile banking. Trust in known and trusted banking institutions does not correlate with any product issued by the bank. The banking sector needs to provide more confidence to its customers about the products that are issued specifically for mobile banking service products. The variation of services available in mobile banking services and network technical factors is still an excuse for some customers to be reluctant to use these services.

\section{Perception of ease of use and actual usage mobile bangking}

The results of this research test provide evidence that the perception of ease of use provides a positive influence and is very convincing both directly and indirectly to the real behavior of mobile banking usage.

314 Management and Economics Journal (MEC-J)

Vol 3 (3) December 2019 
In fact, from the condition of the customers with a background in public service, they are more likely to expect convenience in the mobile banking service application. Technology services for customers who have over the age of 35 provide their own difficulties which contextually have an age delay in getting to know internet technology compared to customers under the age of 35 who have known internet technology services from the beginning and are very familiar with device technology. Customers who are accustomed to using this service, claim to often use mobile banking services without any constraints at all. The easier a technology is used theoretically, the more the technology will be used, while at the same time with the initial goal of the birth of mobile banking services, if customers experience complexity in the application of a technology it will be an additional burden for the older generation who are not yet familiar with the latest technology.

\section{Perception usefulness and actual usage mobile banking}

The findings in the study confirm that the perceptions of usefulness variables are not actually considered important by PNS customers at the Pare branch in shaping the real behavior of mobile banking use. Empirically, the customers already know the benefits of mobile banking services even very well, these benefits are obtained along with the socialization that is often given by banks through brochures or seminars in collaboration with related agencies. However, it seems that the benefit variable is not a variable that is so important for customers to encourage the real behavior of using mobile banking services. These benefits will be proven to be real if customers feel the ease of operation of mobile banking services in their devices, but the evidence is not so that the benefits will be ignored in shaping the real behavior of mobile banking usage. The findings of this study are contradictory to the prerequisites that must be met in the acceptance of a technology service. There is a positive and significant effect simultaneously between the variables of perceived convenience and perceived usefulness. But in this study the benefit variable has no significance even though it has a positive effect which means that this variable is not a primary consideration for customers to use mobile banking services.

\section{The attitude of use and actual usage mobile banking}

The results of the research that have been presented show that the attitude of use is proven to have a direct positive influence on the real behavior of using mobile banking among civil servants but the contribution provided is not significant. These findings prove that the attitude of use in this study is not a variable that is an important consideration for customers at Bank Jatim Pare branch in influencing the real behavior of mobile banking usage.

The attitude towards mobile banking services owned by customers has not been able to shape the real behavior of using mobile banking services. This finding is quite interesting considering that theoretically the attitude would have contributed to the real behavior of the use of mobile banking services, but if it was associated with finding the transaction needs desired by customers, it would find a bright spot in the connection of these conditions. The existence of cash transactions needs to be a useful mobile banking service activity to be used in pare areas, because customers will take cash through independent cash collateral and spend according to their needs. On the side of the need for transfer services that are still minimal and the payment of purchases of electricity 
tokens that do not exist seems to make customers consider mobile banking services have not fulfilled the wishes of customers as a whole. The customer's attitude is also exacerbated by technical conditions such as the availability of internet access at locations where customers are also a separate obstacle that causes customers not to use the mobile banking service.

\section{CONCLUSION}

This study provides empirical conclusions that the perceived ease of use variable is the variable most considered by customers of civil servants at Bank Jatim, both in shaping usage attitudes, influencing customer trust and its contribution to actual usage mobile banking services. This condition is of course quite reasonable considering the prerequisite for receiving a technology is the ease of technology in lieu of the previous technology, if the perception is formed in the customer that mobile banking services are more convenient in their services, customers will gladly switch services.

The contribution of benefit variable perceptions on both attitudinal and actual usage variables proved to be not strong, this condition can be explained because the customer considers that the perception of benefits is considered not important to encourage the use of mobile banking services in the pare area. So the findings also answered the condition of frequent customers being given information, but the use of mobile banking services has not yet increased, this is a bright spot for knowledge accompanied by perceptions of benefits have not been able to shape the attitudes and real behavior of using mobile banking services to customers of Bank Jatim branches Pare.

Trust in this study is considered less important for customers, this is because customers already have good trust in Bank Jatim institutions for a long time. It is no longer a problem for customers regarding trust in institutions. However, banking service products such as mobile banking services are another problem, that trust is not directly attached to trusted institutions but must be proven by the reliability of the features of the mobile banking service.

The attitude toward using also contributes positively in shaping actual usage of the use of Bank Jatim's mobile banking services, but the contribution is not real. Another good finding in this study to describe the problem of the low use of mobile banking services is the need for cash transactions by customers. Most customers need cash transactions in their daily routine compared to the needs of non-cash transactions such as transfers or online purchases, this is what makes the needs of mobile banking services still low.

The testing of the initial model in the design of this study underwent changes, there were additional paths between the ease of perception variables towards the perceived usefulness variables which in this study tested mutual interrelationships that were very meaningful. This model confirms the importance of perceptions of ease in building perceptions of usefulness, besides that this research also shows that the perception of usefulness also contributes to shaping the perception of ease in using mobile banking services at the Bank Jatim Pare branch. 


\section{REFERENCES}

Alsajjan,B. dan Dennis,C. (2010). Internet banking acceptance model: cross-market examination.Journal of Business Research, 63, pp. 0148-2963.

Choi, Jae Young., Yeonbae Kim., Yungman Jun., danYunhee Kim. (2011). A Bayesian Multivariate Probit Analysis of Korean Firms' Information System Adoption, Industrial Management \& Data Systems, 111, (9), pp. 1465-1480

Davis, F.D. (1989) . Perceived Usefulness, Perceived Easy of Use, and User Acceptance of Informatiom Technology. MIS Quarterly, 13, (5), pp. 319-339.

Davis, F.D. (1993). User Acceptance of Information Technology: System Characteristics, User Perceptions and Behavioral. International Journal Management Machine Studies, 38, pp. $475-487$.

Fishbein, $M$ and Ajzen, I. (1975) . Belief, Attitude, Intention, and Behavior: An introduction to Theory and Research Reading. MA: addison-Wesley.

Ferdinand, Augusty. (2002). Sctructural Equation Modeling dalam Penelitian Manajemen. Semarang: Badan Penerbit Universitas Diponegoro.

Ghozali, Imam. (2008). Model Persamaan Struktural : Konsep dan Aplikasi dengan Program AMOS 16.0. Semarang: badan penerbit Universitas Diponegoro.

Islam, S.M. Taohidul., dan Zamri Chik. (2011). Disaster in Bangladesh and Management with Advanced Information System. Disaster Prevention and Management, 20, (5) pp. 521-530.

Kaleem, Ahmad., dan Saima Ahmad. (2008). Banker's Perception of Electronic Banking in Pakistan. Journal of Internet Banking and Commerce, 13,(1), pp. 1-16.

Lech, Przemyslaw. (2012). Information Gathering During Enterprise System Selection: Insight From Practice. Industrial Management \& Data Systems, 112, (6), pp. 964-981.

Maharsi, Sri dan Fenny. (2006). Analisa Faktor-faktor yang Mempengaruhi Kepercayaan dan Pengaruh Kepercayaan Terhadap Loyalitas Internet Banking di Surabaya. Jurnal Akuntansi dan Keuangan, 8, (1), pp. 35-39.

Rigopoulos, George., Dimitrios Askounis. (2007). A TAM Framework to Evaluate User's Perception Toward Online Electronic Payments. Journal of Internet Banking and Commerce, Vol. 12, (3), pp. 1-5.

Suh, B. adan Han, I. (2002). The impact of Customer Trust and Perception of Security on The Acceptance of electronic Commerce. International Journal of Electronic Commerce, Vol. 7 (3), pp. 135-161

Steve Clarke and Mahmood Shah. (2009). E-Banking Management: Issues, Solutions, and Strategies. New York: Information Science Reference. 
